\title{
University Labs As A Training Ground for Teachers
}

\section{Leona Glenn}

Through Title III NDEA many secondary schools have acquired foreign-language laboratories in the past ten years. As we well know such equipment can serve as a valuable tool in developing all foreignlanguage skills, both active and passive, and can help enrich our programs immeasurably. However, the effectiveness of the laboratory depends entirely upon the use made of it and the ability and creativeness of the teachers whom it serves. Unfortunately, many of the language laboratories are being used little or not at all.

In a recent survey, of Ohio public secondary schools, the chief problem listed with laboratories was a lack of maintenance. In most cases, the trouble is in the headphones. Two or three always seem to be out of order, and nobody is available to repair them. Dealers are supposed to maintain the labs, but service is usually slow. Some schools have bought labs with transistorized components parts which may be removed and returned to the factory for repair. If seven out of thirty units are in a factory in Texas, the laboratory in Ohio does not provide much service. Some schools do not have enough student positions for all students. Many have installed partial or portable labs.

Needs listed by the teachers on the questionnairel included: (1) knowledge of ways to correct minor equipment failures, a sort of repair-it-yourself kit; (2) information on preventive maintenance; (3) ways of scheduling for maximum use; (4) techniques for making laboratory drills more palatable to the students.

Many of our beginning teachers have had little or no training on the use to be made of the language laboratory. Since this group is composed of language laboratory directors, no doubt prespective teachers being trained in your institutions are receiving the kind of training they need. However, it may be that your main concern is maintaining, administering and operating a laboratory, rather than training teachers. We discover, too, that certain basic facts are not emphasized, simply because they seem to be so self-evident that we assume the students know them. In our work, it is best to assume that the trainees are starting at zero and proceed from there. Let us take a look at some of the material which should be taught in the colleges and universities before our young teachers go into the classrooms.

'See Appendix A 


\section{University Labs}

In the first place, many of our teachers have only a hazy idea of the purpose of a language laboratory. They neither know what functions it can perform, nor what its limitations are. If students have not been trained by audio-lingual techniques or how to use them the laboratory is just one more item which will confuse them when they get into a classroom.

Unfortunately, many college and university classes do not aim to develop skill in listening and speaking, through such non-intellectual activities as pattern drills. Some have limited laboratory facilities, and larger universities often cannot provide enough equipment to accommodate all students who need the practice a laboratory can provide. It is imperative, however, that those students who are training to teach should have the kind of instruction they will later be expected to provide. Since most teachers are inclined to teach the way they have been taught, let us provide expert examples for them to follow. Proficient teaching includes the use of many media in addition to good textbook material.

Prospective teachers should have some knowledge of the technical aspects of the language laboratory. We do not advocate a complete course in electronics. However, some idea of the way in which the equipment functions is helpful. In order to run a lab well, teachers should know such things as the following: splicing tape; copying records and tapes; cleaning heads on tape recorders; demagnetizing; operating the equipment provided, including recording, all call, adding supplementary recorders, etc. They should have some idea of what is causing equipment malfunction, and what steps should be taken to correct the problem. If the trouble is minor, perhaps only a fuse or a loose connection, they should know what to do about it.

Above all, students should have enough actual contact and experience with laboratory equipment so that they will not be afraid of it. or afraid to use it.

All of this training can best be given through work experience. All prospective language teachers should be required to spend a quarter or more working in the laboratory. It is easier for you to do it yourself, than to teach somebody else how to run and take care of the equipment. However, you are depriving your students of essential training if you omit this part of their pre-service professional preparation.

There are other reasons for technical training. Many teachers are called upon by their administrators to help design laboratories and choose equipment. They should have training in planning laboratories for a variety of school situations and in writing specifications for the equipment. Too many laboratories have been installed without consulting the people who will use them. The result is often impractical, sometimes completely non-functional. 
When designing laboratory facilities and writing specifications, the total installation plans should include provision for the use of audiovisual equipment, such as moving pictures, slide, filmstrip, overhead, and opaque projectors. Students should be informed about everything from having the conduits placed before the concrete is poured to light and acoustic control. And don't forget about such things as the storage of materials, work space, and sound proof rooms for recording.

Many schools are now installing listening centers in the library. The proper equipment for study carrells, cataloging and use of materials in these centers, should be considered.

In their work with the language laboratory, teachers must know how to schedule its use for maximum utility. In some high schools, it is possible to assign lab periods for individual students in addition to class time. Since we feel that such work should be monitored, this may require more teacher time than is available. Additional staff requires more money, which most school systems are reluctant to spend on foreign language instruction.

If classes are assigned certain periods in the laboratory, the schedule needs to be carefully planned, so that all classes have adequate drill time provided. In many schools, classes are grouped around the lab, and half-period sessions are provided by exchange of groups. Often a less complete installation, in several classrooms is preferable. Teachers find this to be more flexible, since it can be used when most needed.

Don't give your students the idea that they can't work in anything less than a laboratory complete with booths and recording equipment. Few will work in a school where such facilities are supplied. Rather, give them many ideas about how to use any equipment at all, beginning with one tape recorder and/or one record player, and have them learn how to extend its usefulness.

We find that some of our teachers evidently have the impression that the laboratory will do their work for them. Some do not even put on their earphones. They put on a tape, and let the pupils take it from there.

It may not be your job, but someone must help these young people learn how to establish behavioral objectives, choose the best materials to achieve them, and to evaluate the results. The all-important correlation of laboratory drill and class work would seem to be self-evident. The number of drill sessions which are not related to the text materials in any way is surprising.

There are other facts our teachers should learn before going out to teach.

1. How do you orient the students to lab work, and how often must it be done?

2. How do you work most effectively with individual students 


\section{University Labs}

in the lab? Do you interrupt the drill for explanation and cause them to miss some items?

3. How can the lab be used to provide for individual differences?

4. What kinds of materials are available and where may they be obtained?

5. How can the lab be used for testing?

6. What is the most practical way to store material so it will be readily available?

7. How should material be catalogued and marked?

Other basic considerations teachers must be aware of are:

1. Do we practice in the lab with books open or closed?

2. Do we introduce new material in class or can it be presented first in lab?

3. How often should the lab be used?

4. What is the maximum length of time for a drill session?

5. How many times should pattern drills be repeated?

6. How do we help students recognize their mistakes and how do we help correct them?

7. What is the best way to use the lab when presenting cultural materials?

8. How can the lab help develop literary appreciation?

9. Can the lab be used to help students learn skills other than aural-oral?

10. What are some good ways for monitoring and evaluating the work of the student?

11. How can students be motivated to use the lab?

These are only a few of the basic facts you as lab teachers should present to your students. They are based upon psychological and/or linguistic principles, educational theory and practice, and consideration of the needs and desires of the students.

One of the most important facets of all foreign-language training is the question of motivation. Of all instructional procedures, the motivation of the laboratory practice is perhaps the hardest. Students are often indifferent or bored during lab sessions. They endure the practice session, as they endure a large percentage of all their schoolday because they have no choice. However, if research shows that the use of the language laboratory makes little or no significant difference in achievement of proficiency, certainly part of the blame can be traced to a lack of motivation, as well as to many current practices which are somewhat less than effective.

No doubt you think this is a tall order. Much of it should be a part of the methods class. The methods teacher and laboratory director should correlate their work so that the content can all be included in 
the most suitable context. Even so, one quarter or semester is scarcely enough training.

Then there is the problem of the teachers already in service. We would hope that all members of the NALLD would be knowledgeable in the field of language methodology as well as in the language laboratory and its use. If all colleges and universities could have someone available to provide additional training, service, advice, and information to schools in their area, a great service would be provided for teachers and schools and foreign-language study in general. Ohio has an institution of higher learning within 30 miles of every prospective student in the State. It would seem to be possible for these centers to help the schools near them.

Such service would and should be paid. Any school which installs a $\$ 10,000$. lab should be willing to pay $\$ 25, \$ 50$, or even $\$ 100$, to keep it functioning.

Training for teachers, and even for their students who serve as lab assistants might help get the dust off the labs and put them into use. Work is equally important.

If language laboratories are to continue, it is up to such organizations as NALLD to take the lead in keeping them functional. This is our challenge today.

About the Author: Miss Glen is Title III NDEA Supervisor for the State of Ohio. 
University Labs

Appendix $A$

LANGUAGE LABORATORY QUESTIONNAIRE

School

City

Address

Exempted Village

County

No Equipment for Individual Student Use

I. Number of student positions:

Listen - repeat - record

Listen - repeat only

Listen only

II. Kind of installation:

Booths

Tables

Student desks

Ceiling

Floor

Wireless

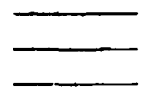

III. Console equipment:

Tape lesson sources

Cartridge sources

Record player

IV. Additional information

1. Main problems with equipment

2. Kind of information or help needed.

SEND TO: Miss Leona Glenn

Title III, NDEA, Dept. of Education

Consultant, Modern Foreign Languages

$986 \mathrm{~W}$. Goodale Blvd.

Columbus, Ohio 43212 